\title{
Ph.d-afhandling om testikulær mikrolithiasis
}

D. 4 oktober 2018 forsvarede Malene Roland Pedersen fra Røntgenafdelingen Vejle Sygehus sin PhD. Titlen på PhD afhandlingen var Imaging aspects of testicular microlithiasis, hvor der var hovedvægt på ultralyd. PhD afhandlingen undersøgte testicular microlithiasis, hvor vævselasticiteten blev målt med ultralyd shear wave elastografi. Målingerne blev sammenlignet med patienter som havde normal testikel væv og patienter med testikelcancer. Ultralyd elastografi målingerne blev desuden også sammenlignet med MRI diffusion. PhD afhandlingen fandt ikke at testicular microlithiasis skulle være forstadie til testikelcancer.

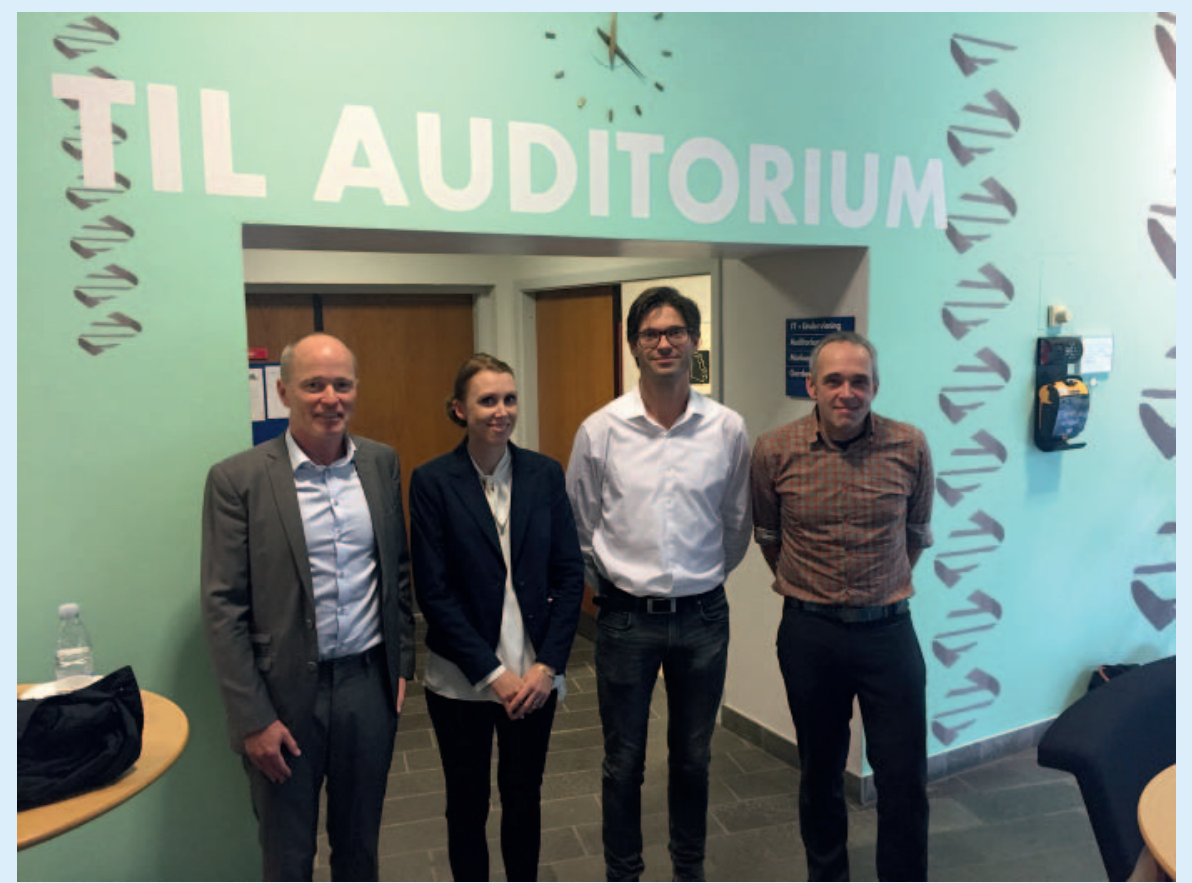

På billedet ses Chairman ledende overlæge Jens Karstoft fra OUH, Malene samt opponenterne overlæge, PhD Kristoffer Lindskov Hansen fra Rigshospitalet og PhD Carsten Lauridsen fra Professionshøjskolen Metropol. 